This item was submitted to Loughborough's Research Repository by the author.

Items in Figshare are protected by copyright, with all rights reserved, unless otherwise indicated.

\title{
Using art therapy techniques to explore home life happiness
}

PLEASE CITE THE PUBLISHED VERSION

http://www.inter-disciplinary.net/probing-the-boundaries/tranquillity-studies/happiness

\section{PUBLISHER}

(c) Inter-Disciplinary Press.

\section{VERSION}

AM (Accepted Manuscript)

\section{PUBLISHER STATEMENT}

This work is made available according to the conditions of the Creative Commons Attribution-NonCommercialNoDerivatives 4.0 International (CC BY-NC-ND 4.0) licence. Full details of this licence are available at: https://creativecommons.org/licenses/by-nc-nd/4.0/

\section{LICENCE}

CC BY-NC-ND 4.0

\section{REPOSITORY RECORD}

Doyle, Emily Corrigan, M. Carolina Escobar-Tello, and Kathy Pui Ying Lo. 2019. "Using Art Therapy Techniques to Explore Home Life Happiness". figshare. https://hdl.handle.net/2134/20783. 


\title{
Using Art Therapy Techniques to Explore Home Life Happiness
}

\author{
Emily Corrigan-Doyle, Carolina Escobar-Tello \\ and Kathy Pui Ying Lo
}

\begin{abstract}
The home plays many roles in our daily lives. It provides shelter and a place to rest. It can be viewed as an extension of the self, portraying our hopes and ideals, and where we create our identity within society ${ }^{1}$. However, contemporary homes are filled with modern appliances that offer few opportunities for creative output or experience, reducing potential for self-reflection and psychological growth.

This lifestyle of high consumption and productivity does not correlate with long-term happiness ${ }^{2}$ but engagement in creativity does ${ }^{3}$. Furthermore, art creation engages the emotional centres of the brain ${ }^{4}$ so can potentially be used to investigate and enhance happiness in the home. In particular, art therapy techniques (for example, art making in silence) can be used to trigger and explore positive emotions. Also, service design approaches (for example, experience journey maps) can facilitate the conceptualisation of new experiences, including happier ones.

Based in the UK, this research will therefore explore how creativity can contribute to happiness in the domestic space by using approaches from art therapy and service design. A series of workshops, comprising family homeowners and later service designers, guided by the researchers, will use techniques from these fields to investigate how home happiness might be developed/facilitated. The first of these workshops tested the use of art therapy techniques. This paper will present initial findings from this, such as creating the right context for reflective art making, facilitating emotional expression and art making with a focus on positive family time.
\end{abstract}

Key Words: Creativity, happiness, home, art therapy techniques, service design, emotions, flow, new experiences.

$* * * * *$

\section{Introduction}

According to Nakamura and Csikszentmihalyi, a happy life is one that contains moments of flow - the complete absorption in what one does, using personal strengths to master challenges ${ }^{5}$. Art making has been documented in art therapy to encourage experiences of flow ${ }^{6}$. Art creation has also been linked to the expression of positive emotion, including happiness. Furthermore, it has been shown by research using fMRI scans, to provide alternative access to emotional centers in the brain when emotional mood drawings are created as this appears to activate corresponding neurological areas ${ }^{7}$. This suggests that art therapy techniques can be used to elicit positive emotional responses and explore happiness. In this research, 
they were used to investigate positive experiences in the home.

\subsection{The Creative and Influential Home}

The human need for self-expression can clearly be witnessed in the home. "The showcase of the self" refers to the human tendency to gather, arrange and display artefacts of emotional and social relevance in this space to develop a personal representation within a particular social context ${ }^{8}$. Home is "a shelter for those things that make life meaningful", , a reminder of those attributes we respect and those we feel we are lacking ${ }^{10}$. Accordingly, it is an evolving space $^{11}$, full of dialectic practices between individuals, objects and society ${ }^{12}$.

Homes in this manner can influence our behaviour. For example, it can encourage social interaction by providing inviting communal spaces. Furthermore, our daily habits can influence up to $40 \%$ of our experienced happiness ${ }^{13}$. Homes, by enabling certain activities or not, can affect our happiness.

\subsection{Contemporary Domestic Lifestyles}

However, contemporary consumerist lifestyles have resulted in many homes filled with commercial design products and appliances that discourage positive engagement. This is because most of modern design offers few opportunities for creativity ${ }^{14}$ and instead, arguably, focus on satisfying biological needs for pleasure. Csikszentmihalyi ${ }^{15}$ characterises pleasure as the harmonious feeling resulting from a physiological need (for example, sleep) being met. However, solely fulfilling pleasure needs in the home cannot bring happiness as this subsequently creates contexts of productivity and evanescence that lack emotional complexity. Life must also have experiences of enjoyment, those that contain novelty, a sense of accomplishment (i.e. the development of a new skill) and instances of flow ${ }^{15}$. Evidently, current lifestyles of high consumption do not necessarily correlate with long-term happiness and have been linked to higher levels of depression ${ }^{16}$.

\subsection{Happiness in the Home}

Notably, research has shown that the existence of strong social relationships can lead to higher levels of reported happiness ${ }^{17}$ and these could be facilitated in the home. Findings from the previous study ${ }^{18}$ of this research supported this in which photo elicitation was used as a combined interview and creative method. 13 participants from home-owning families created photographic narratives of their domestic routines, later discussing these in semi-structured interviews. This caused them to deeply reflect about happiness triggers in the home and revealed several needs for home life happiness. The most prominent of these needs were self-love, reciprocal love and companionship in which positive time spent with family (for example, relaxing together) appeared to satisfy these needs simultaneously. It was therefore decided to continue to use image making (i.e. art therapy techniques) to explore the happiness aspects of positive time with family in greater detail through a series of workshops. This paper will present findings from the first of these 
workshops.

\section{Using Art Therapy Techniques to Explore Happiness in the Home}

Art therapy is a type of psychotherapy that uses art creation to treat physiological and mental disorders or to aid in self-development ${ }^{19}$. In this, techniques such as silence and spontaneous art making can be used to help participants visualise feelings and thoughts that are difficult to verbalise ${ }^{20}$ and outsider interpretation of resulting artefacts is mostly discouraged ${ }^{21}$ to promote emotional authenticity ${ }^{22}$.

This workshop tested the appropriateness of art therapy techniques for the exploration of positive family time. Given their usual therapeutic setting, it was essential to trial these creative techniques in a preliminary study so that the most appropriate could be identified, modified if necessary and brought forward in later workshops.

\subsection{Participants}

This was a pilot study to test the viability of art therapy techniques to explore home life happiness. Furthermore, it is recommended for the numbers in a group art therapy session to be kept low (between 6 and 12) to afford each individual adequate attention $^{23}$, so the group was intentionally kept small. Participants in this pilot study consisted of two male and two female, aged between 27 and 55 from different disciplinary backgrounds.

\subsection{Procedure}

This preliminary workshop was performed at an appropriate venue for art therapy techniques. The room was close to a sink (for washing brushes and hands), it had large windows (for natural light), and had ample table space and areas to work on and hang $\mathrm{art}^{24}$. The workshop was planned to last a total of 1.5 hours and was divided into three tasks. The activities and their purpose are summarised in order of occurrence in the table 1.

Table 1: Tasks and procedures followed in workshop and rationales 


\begin{tabular}{|c|c|c|}
\hline Task & Procedure & Rationale \\
\hline $\begin{array}{c}\text { Activity } 1 . \\
\text { Image awareness } \\
\text { exercise }\end{array}$ & $\begin{array}{l}\text { Prior to the workshop, } \\
\text { participants were asked to pick } \\
\text { an area in their homes where } \\
\text { they spent the most time and } \\
\text { carefully observe the imagery } \\
\text { around them, making reflective } \\
\text { notes and/ or drawings on what } \\
\text { they liked or didn't like, would } \\
\text { like more of or would like to } \\
\text { change. For the first activity of } \\
\text { the workshop participants were } \\
\text { asked to share their outcomes } \\
\text { with the group. }\end{array}$ & $\begin{array}{l}\text { This was applied to establish initial } \\
\text { interest before the workshop and to } \\
\text { make participants more aware of } \\
\text { significant images they kept in their } \\
\text { personal spaces. In this manner, it was } \\
\text { to help them draw meaning from later } \\
\text { resulting artworks because the } \\
\text { unconscious mind is influenced by } \\
\text { images and this can influence the } \\
\text { artwork that one creates }{ }^{24} \text {. } \\
\text { Furthermore, asking participants to } \\
\text { share these outcomes at the workshop } \\
\text { was used as an icebreaker activity. }\end{array}$ \\
\hline $\begin{array}{l}\text { Activity } 2 \text {. } \\
\text { Spontaneous art } \\
\text { making }\end{array}$ & $\begin{array}{l}\text { Participants were given a black } \\
\text { outline of a house as a template } \\
\text { to decorate the page using any } \\
\text { of the materials available } \\
\text { without speaking. Once this } \\
\text { time was up, they were each } \\
\text { requested to explain the image } \\
\text { they had created to the rest of } \\
\text { the group. }\end{array}$ & $\begin{array}{l}\text { This spontaneous art making } \\
\text { technique was used to allow } \\
\text { participants to visually free associate } \\
\text { what home meant to them. Discussing } \\
\text { their imagery with the group } \\
\text { afterwards was used to assist } \\
\text { participants in initially reflecting and } \\
\text { understanding the meaning of their } \\
\text { artefact }^{24} \text {. It was also to encourage } \\
\text { collective learning }^{25} \text { as these overt } \\
\text { contemplations might serve to trigger } \\
\text { insights for other participants about } \\
\text { the significance of their own artwork }\end{array}$ \\
\hline $\begin{array}{l}\text { Activity } 3 . \\
\text { Visualising } \\
\text { positive family } \\
\text { time }\end{array}$ & $\begin{array}{l}\text { Participants were asked to } \\
\text { visualise a positive experience } \\
\text { with family members using any } \\
\text { of the materials provided, again } \\
\text { without speaking. Lastly, they } \\
\text { were then asked to individually } \\
\text { discuss their images i.e. what it } \\
\text { represented and reasons for } \\
\text { their chosen colours, shapes, } \\
\text { sizes and forms. }\end{array}$ & $\begin{array}{l}\text { Having become more sensitised } \\
\text { visually and emotionally to their } \\
\text { personal understanding of home from } \\
\text { previous exercises, this session was } \\
\text { used to focus participants' attention } \\
\text { on the concept of positive family time. }\end{array}$ \\
\hline
\end{tabular}


The workshop facilitator used the 'participant observation' approach and took on the role of 'participant-as-observer' ${ }^{26}$. Instructions for activities were narrated to participants and were also demonstrated (i.e. through pictorial examples) to help participants understand the workshop's expectations.

At the end of the workshop, participants completed a feedback form and unstructured interviews ${ }^{26}$ were carried out to clarify their initial thoughts about the session. Due to the reflective nature of the workshop it was deemed important to allow participants additional time to consider their experiences. To that end, oneto-one semi-structured interviews ${ }^{26}$ were carried out with participants a few days after the workshop.

\subsection{Analysis Strategy}

The workshop and interviews' data (video, audio footage, field notes) was analysed for evidence of deep reflection around home happiness. This was done using analytical memos, session summary sheets ${ }^{26}$ and sensitising questions ${ }^{27}$.

Full transcriptions were created from the audio recordings of the workshop and semi-structured interviews in order to sensitise the investigator to responses that illustrated relevant deep reflection. Analytical memos were utilised to clarify overall impressions after the workshop sessions and semi-structured interviews. Sensitising questions (i.e. How is this scenario encouraging reflection about positive family time?) were then used to amplify important aspects that indicated reflection in participants such as facial expressions of intense contemplation.

\section{Results and Discussion}

The analysis of the results identified applicable techniques that facilitated participants' deep reflection and expression of feelings, both visually and verbally, to take forward in subsequent workshops. The ability of art therapy techniques to induce positive affect and generate insights around positive family time was also indicated. These findings will be discussed in detail in the following sections.

\subsection{Creating the Right Context for Reflective Art Making}

Activity 1 discussions suggested that the preparatory image awareness exercise triggered participants' interest in the workshop prior to the session. It seemed to stimulate reflection about their aesthetical preferences for visuals in their surroundings and the significance of this (i.e. how these enforced or could facilitate their happiness). For example, one participant observed after doing this exercise that his current home environment felt more like an office space as his main living area was quite bare. In this, he remarked that he would like to change "the office shelves" for a "more homely oval" bookcase because otherwise "you just feel like you're at work... 24 hours a day". It thus appeared to create the right context for later artistic expression aimed at illustrating feelings (i.e. the happiness aspects of 
positive family time) as oppose to rational thoughts. Furthermore, as they were given the freedom to illustrate their results through writing or imagery - with two out of four participants using both - it encouraged participants to start thinking about their feelings visually.

Additionally, the use of spontaneous image making in activity 2 appeared to serve as an adequate warm-up exercise towards art making. It allowed participants to select and experiment with any medium of their choosing to create randomised imagery. Participants were initially timid in approaching the materials but their confidence appeared to improve over time. For example, by activity 3 all participants had transitioned from just using one form of medium (i.e. colouring pencils) to using many simultaneously (i.e. coloured paper, crayons, glue) (see image 1).

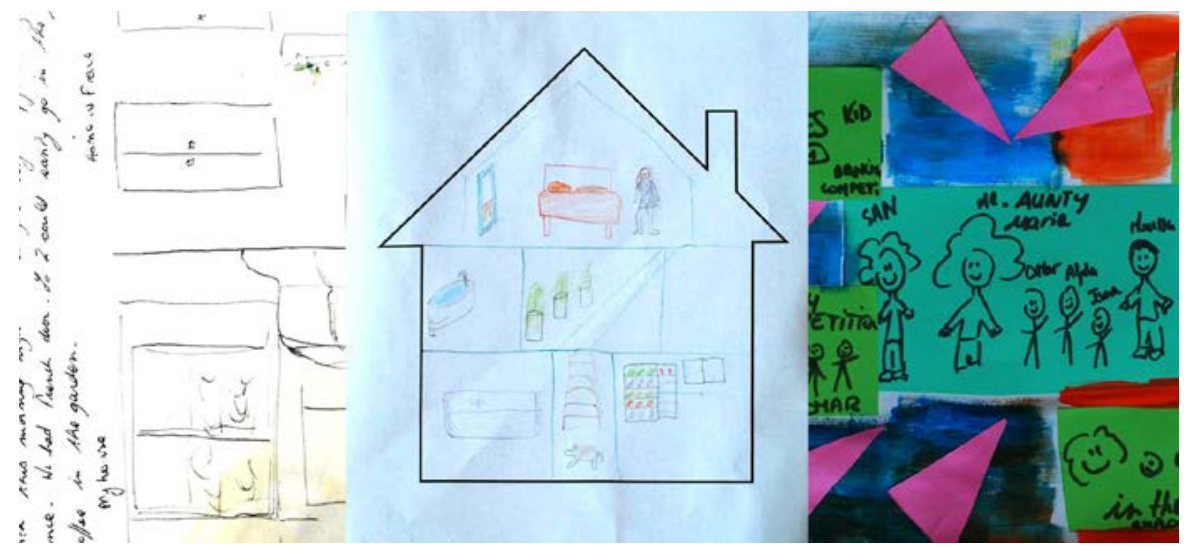

Image 1: Read from left to right, this image shows notes and drawings from the activity 1 (image awareness exercise), then artwork from activity 2 (spontaneous art making) and activity 3 (visualising positive family time).

However, as different materials were placed at different points of the table where the participants were seated, this appeared to influence their material choices. For example, piles of magazines placed at the end of the table were left untouched for the duration of the workshop. Accordingly, materials could be evenly dispersed within easy reach of participants in future workshops to limit this.

Nonetheless, the resulting artwork was very personal to each individual and, consequentially, incoherent to the facilitator without additional explanations. This provided a safeguard against making personal evaluations of the artwork and dismissing participants' feedback. Collectively, the techniques appeared to emphasise participants' individuality i.e. how they thought of the world differently (see image 2 below). 


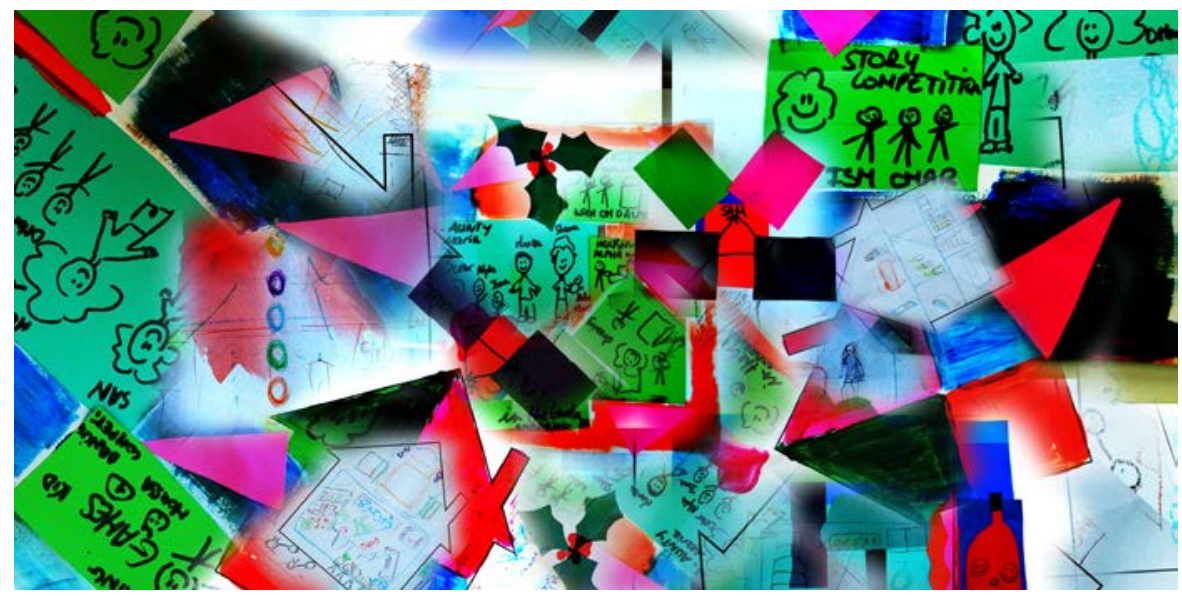

Image 2: A montage of all artwork created during the workshop, detailing its mostly abstract and ambiguous quality.

\subsection{Inducing Experiences of "Flow"}

Evidently, by providing participants with a variety of materials to use and gradually advancing the tasks, participants appeared to experience periods of flow ${ }^{30}$ during the session. For instance, as the preparatory activity allowed them to document their thoughts through illustration or writing and activities 2 and 3 allowed freedom of material use, participants could engage in the tasks at their own level and pace, advancing their activity when ready.

Furthermore, all participants stated that conducting the art making in silence (activity 2 and 3) greatly aided in their concentration and immersion in the tasks. They asserted that discussions might have influenced the content of the resulting imagery. Observing participants silently working on artwork during the workshop and subsequently using the recorded video footage further confirmed this. Participants appeared to be heavily engaged in the tasks - their gestures and body language (i.e. contemplative expressions and pauses followed by meditated actions) indicated that they were carefully selecting materials and making thoughtful decisions about their compositions. Subsequently, all resulting artworks were very unique and different when compared collectively (see image 3). 


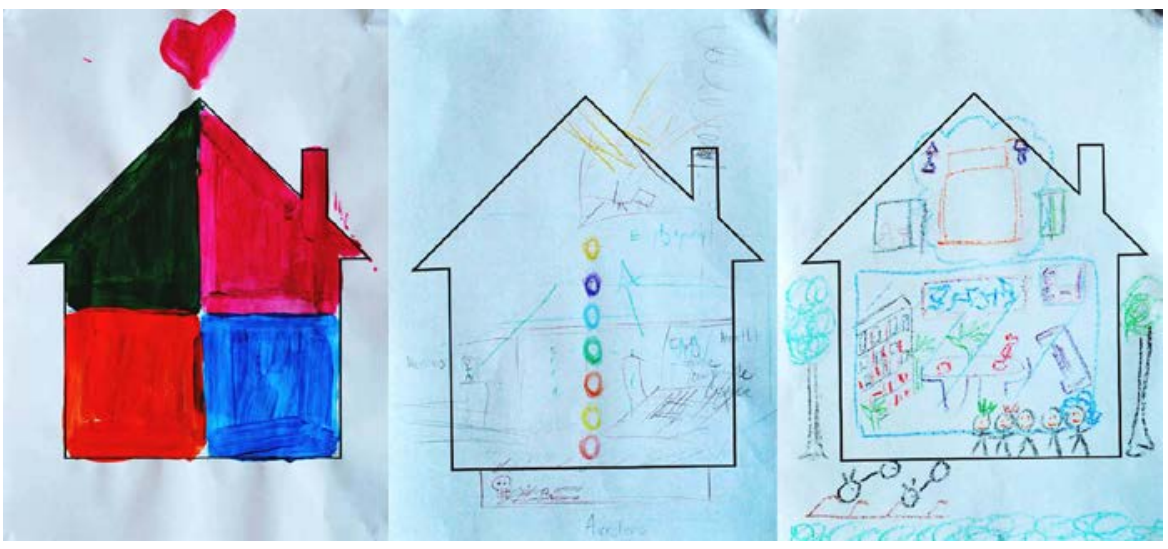

Image 3: A selection of images created during activity 2 (spontaneous art making).

\subsection{Facilitating Emotional Expression}

The image awareness exercise appeared to trigger appropriate responses in participants (i.e. descriptions of how they felt as opposed to what they thought of their surroundings) prior to the workshop, engaging them emotionally about their visual preferences.

The periods when talking was permitted (end of activity 2 and 3) appeared to give participants a platform in which they could share their insights with the rest of the group while limiting distraction from the art making process itself and rationalising of imagery. By requiring participants to immediately discuss their artwork or listen to others speak about theirs, they were forced to express or hold onto their initial reactions before these became distorted by conscious reconsideration. This was made evident by three out of four participants overtly reassessing what they were saying while they were explaining their image to the group. Such comments included, "I have somehow managed to dismiss my entire family" and "They're like chakras ... maybe half of them should be missing".

Additionally, throughout the workshop the facilitator maintained a neutral composure with participants, not offering any interpretations about images while using eye contact and head nods to assume an attentive stance. As with similar interview techniques (i.e. neutral questioning), ${ }^{28}$ this enabled participants to express their thoughts without interruption and, consequently, aided in the creation of a suitable context for open reflection.

Admittedly, not all participants would be comfortable sharing their reflections in a group scenario or would understand their imagery completely. It was therefore deemed suitable to hold semi-structured interviews with participants after the workshop to accommodate a more private space for honest responses and allow participants additional time to reflect. Further review of relevant literature also 
confirmed this as a viable approach as the meaning of the artwork could change for participants over time ${ }^{29}$.

\subsection{Art Making with a Positive Focus - Positive Family Time}

Activity 3 seemed to be effective in enabling participants to be emotionally reflective about positive family time. For example, one participant remarked, "The best type of memories I have with family are talking about your problems" and another described, "There's my family with the bottle [of wine] and that's how I picture the summer". Evidently, because they had to dictate all elements of the image, each participant needed to carefully consider all aesthetical choices in relation to what they were trying to portray. Consequently, this appeared to encourage some to think carefully about the roles each family member played in positive family experiences. For instance, one participant explained why each person was a specific colour and were placed at certain points on the page:

These are my sisters who are identical twins. That's why they're the same colour and this sort of grey box down here is my mother... doesn't really fit into what was a tight nit group... [partner] and I are under here because we do hold the whole group together.

Naturally, some participants were more reflective than others and were better able to give detailed accounts of positive family experiences. Nonetheless, it was clear that all reported experiences shared two qualities; they facilitated the expression of family members' strengths and encouraged experiences of flow ${ }^{30}$. For example, one participant described a rewarding weekend where she had to look after her nephews because she is "the responsible one" who entertains the children. Although the experience was tiring, being with them made her "feel whole". Evidently, asking participants to focus on and visualise a positive family experience appear to amplify their momentary happiness by affirming the presence of this in their life. During the follow-up unstructured interviews, all participants reported that they felt very positive from the experience and wished for it to last longer. In this manner, the workshop also appeared to facilitate a platform for acknowledging the good things in one's home life. Accordingly, this positive affect could encourage greater responsiveness from participants in follow-up semistructured interviews in subsequent workshops.

\section{Conclusions}

This workshop provided an enjoyable experience for participants while reaffirming positive aspects of home life. The art making afforded an expressive communication tool for individuals to illustrate their unique thoughts and desires around similar topics at their own pace and level. The image awareness exercise 
was effective in generating initial interest about the workshop activities. It engaged participants in the visual aspects of their surroundings and its impact on their happiness i.e. the need for separation between work and home.

Activity 2 (spontaneous art making) gave participants a chance to practice with the materials and proved useful in eliciting relevant responses around home, for example, what it meant to them. After conducting these tasks, participants were sensitised to personally significant domestic imagery - by first being made aware of meaningful imagery in their everyday life (i.e. image awareness exercise) and then specifically those related to home (i.e. spontaneous art making activity).

Activity 3 (visualising positive family time) allowed them to focus on positive experiences with family members and illustrate these. Collectively, the three workshop activities (i.e. activity 1, 2 and 3) combined to allow participants a gradual transition from familiar materials (i.e. pencil) to those that were more adventurous (i.e. collage). Furthermore, conducting these activities in silence enabled participants to concentrate on tasks, minimising influence from others. This resulted in all artworks being very personal in appearance, necessitating accompanying comments from participants to clarify meaning. This would therefore reduce the risk of personal biases influencing findings in later workshops. However, it was also noted that participants might not feel comfortable discussing reflections in a group and the meaning of the artwork might change over time. Subsequent sessions would hence include follow-up semi-structured interviews a week after the workshop.

Nonetheless, the resulting images appeared to ease this process as they provided participants with reference points for discussions when sharing insights with the group. Furthermore, as all elements of the image where dictated by the individual, each needed to consider their aesthetical choices, especially when explaining this to the group. This also encouraged individuals to think about the roles each family member played and the events that lead to positive experiences with them. This evidently lead to the preliminary identification of possible conditions for positive family experiences i.e. utilisation of one's strengths and experiences of flow $^{30}$, that could be further explored in subsequent workshops with semi-structured interviews. Having been sensitised to their personal happiness triggers around positive family time during the workshop, participants would be in a stronger position to deliver insightful answers around these topics. Relevant questions for each participant based on their workshop responses could also be formulated to explore how time with family using one's strengths or experiencing flow $^{30}$ might be facilitated within the home. Following this process, art therapy techniques could potentially make a valuable contribution to the understanding of happiness in the home.

\section{Future Work}

This preliminary study confirmed the effectiveness of art therapy techniques in promoting personal emotional connection and demonstrated strong potential in 
investigating positive family time in the home. The next stages of this research will use these techniques in the second study workshops to explore the concept of positive family time intensely i.e. how the expression of personal strengths and experiences of flow $^{30}$ are facilitated in these instances. Subsequently, these results will be used by service designers in a final workshop to create design interventions for the facilitation of happy experiences in the home.

\section{Notes}

${ }^{1}$ Antonio Cristoforetti, Francesca Gennai and Guilia Rodeschini, "Home sweet home: The emotional construction of places,” Journal of Aging Studies 25, no. 3 (2011): 225-232.

Alain De Botton, The Architecture Of Happiness (London: Penguin Group, 2006).

2 Patrick Hofstetter, Michael Madjar and Toshisuke Ozawa, "Happiness and Sustainable Consumption: Psychological and physical rebound effects at work in a tool for sustainable design Patrick,” Int J LCA 11, no. 1 (2006):105-115.

${ }^{3}$ Mihalyi Csikszentmihalyi, Flow: The Psychology of Happiness: The Classic Work on How to Achieve Happiness (USA: Harper \& Row, 2002).

${ }^{4}$ Vija B. Lusebrink and Palo Alto, "Art Therapy and the Brain: An Attempt to Understand the Underlying Processes of Art Expression in Therapy,” Art Therapy: Journal of the American Art Therapy Association 21, no. 3 (2004): 125-135.

5 Jeanne Nakamura and Mihalyi Csikszentmihalyi, "The Concept of Flow," in Handbook of Positive Psychology, ed. Charles R. Snyder and Shane J. Lopez (Oxford: Oxford Univeristy Press, 2002), 89-105.

6 Amy Voytilla, "Flow states during art making," MA diss., (The School of the Art Institute of Chicago, 2006).

7 Vija B. Lusebrink and Palo Alto, "Art Therapy and the Brain: An Attempt to Understand the Underlying Processes of Art Expression in Therapy,” 125-135.

${ }^{8}$ Cristoforetti, Gennai and Rodeschini, "Home sweet home: The emotional construction of places," 225-232.

${ }^{9}$ Mihalyi Csikszentmihalyi and Eugene Rochberg-Halton, The Meaning of Things: Domestic Symbols and the Self (Cambridge: Cambridge University Press, 1981), 139.

${ }^{10}$ Alain De Botton, The Architecture Of Happiness.

${ }^{11}$ Kimberly Dovey, "Home and Homelessness: Introduction," in Home Environments. Human Behavior and Environment: Advances in Theory and Research, eds. Irwin Altman and Carol M. Werner (New York: Plenum Press, 1985), 33-64.

${ }^{12}$ Tim Ingold, Being Alive: Essays on Movement, Knowledge and Description (London: New York: Routledge, 2011). 
13 Sonja Lyubomirsky, Kennon M. Sheldon and David Schkade, "Pursuing Happiness: The Architecture of Sustainable Change," Review of General Psychology 9, no. 2, (2005): 111-131.

${ }^{14}$ Elizabeth Sanders and Pieter Jan Stappers, "Co-creation and the new landscapes of design,” CoDesign 4, March, (2008): 5-18.

${ }^{15}$ Mihalyi Csikszentmihalyi, Flow: The Psychology of Happiness: The Classic Work on How to Achieve Happiness, 46.

${ }^{16}$ Patrick Hofstetter, Michael Madjar and Toshisuke Ozawa, "Happiness and Sustainable Consumption: Psychological and physical rebound effects at work in a tool for sustainable design Patrick," 105-115.

Ed Diener and Martine Seligman, "Beyond Money: Towards an Economy of Wellbeing,” American Psychology Society 5, no. 1, (2004): 1-31.

${ }^{17}$ Ed Diener and Martin Seligman, "Very Happy People," American Psychology Society 13, no. 1, (2002): 81-84.

${ }^{18}$ Emily Corrigan-Doyle, Carolina Escobar-Tello and Kathy Pui Ying Lo, “Taking a Softer Approach: Using Photo Elicitation to Explore the Home as a System for Happiness and Sustainability” (paper presented at $20^{\text {th }}$ Sustainable Innovation, UCA, Surrey, November 9-10, 2015).

${ }^{19}$ Cathy Malchiodi, The Art Therapy Sourcebook $2^{\text {nd }}$ Edition (Hove: New York: Bruner-Routledge, 2007).

${ }^{20}$ Cathy Malchiodi, The Art Therapy Sourcebook $2^{\text {nd }}$ Edition.

Cathy Malchiodi, The Handbook of Art Therapy (New York: The Guilford Press 2003).

Judith A. Rubin, The Art of Art Therapy: What Every Art Therapist Needs to Know (Routledge: New York: East Sussex, 2011).

${ }^{21}$ Liesl Silverstone, Art Therapy Exercises: Inspirational and Practical Ideas to Stimulate the Imagination (London: Jessica Kingsley Publishers, 2009).

Cathy Malchiodi, The Art Therapy Sourcebook $2^{\text {nd }}$ Edition.

Judith A. Rubin, The Art of Art Therapy: What Every Art Therapist Needs to Know.

${ }^{22}$ Judith A. Rubin, The Art of Art Therapy: What Every Art Therapist Needs to Know.

${ }^{23}$ Marian Liebmann, Art Therapy for Groups: A handbook of themes and exercises (Hove: New York: Bruner-Routledge, 2004).

${ }^{24}$ Cathy Malchiodi, The Art Therapy Sourcebook $2^{\text {nd }}$ Edition.

${ }^{25}$ Marian Liebmann, Art Therapy for Groups: A Handbook of Themes, Games and Exercises (New York: Routledge, 1986).

${ }^{26}$ Colin Robson, Real World Research: A Resource for Social Scientists and Practitioner - Researchers 3rd Edition (Oxford: Blackwell Publishers ltd, 2011).

${ }^{27}$ Juliet Corbin and Anselm L. Strauss, "Bringing Process into the Analysis" in Basics of Qualitative Research: Techniques and Tools for Developing Grounded Theory (Thousand Oaks: SAGE Publications, 2008), 247-263. 
${ }^{28}$ Colin Robson, Real World Research: A Resource for Social Scientists and Practitioner - Researchers 3rd Edition.

${ }^{29}$ Cathy Malchiodi, The Art Therapy Sourcebook $2{ }^{\text {nd }}$ Edition.

Cathy Malchiodi, The Handbook of Art Therapy.

${ }^{30}$ Mihalyi Csikszentmihalyi, Flow: The Psychology of Happiness: The Classic Work on How to Achieve Happiness.

\section{Bibliography}

Corbin, Juliet and Anselm L. Strauss. Basics of Qualitative Research 3rd Edition. Thousand Oaks: SAGE, 2008.

Corrigan-Doyle, Emily, Carolina Escobar-Tello and Kathy Pui Ying Lo, "Taking a Softer Approach: Using Photo Elicitation to Explore the Home as a System for Happiness and Sustainability" (paper presented at $20^{\text {th }}$ Sustainable Innovation, UCA, Surrey, November 9-10, 2015).

Cristoforetti, Antonio, Francesca Gennai and Guilia Rodeschini "Home Sweet Home: The Emotional Construction of Places,” Journal of Aging Studies 25, no. 3 (2011): 225-232.

De Botton, Alain. The Architecture of Happiness. London: Penguin Group, 2006.

Diener, Ed. and Martin E.P. Seligman. "Beyond Money: Towards an Economy of Wellbeing.” American Psychology Society 5, no. 1, (2004): 1-31.

Diener, Ed. and Martin E.P. Seligman, "Very Happy People." American Psychology Society 13, no. 1, (2002): 81-84.

Dovey, Kimberly. 'Home and Homelessness: Introduction.' In Home Environments. Human Behavior and Environment: Advances in Theory and Research, edited by Irwin Altman and Carol M. Werner, 33-64. New York: Plenum Press, 1985.

Hofstetter, Patrick, Michael Madjar and Toshisuke Ozawa, "Happiness and Sustainable Consumption: Psychological and physical rebound effects at work in a tool for sustainable design Patrick.” Int J LCA 11, no. 1 (2006): 105-115.

Ingold, Tim. Being Alive: Essays on Movement, Knowledge and Description. London: New York: Routledge, 2011. 
Liebmann, Marian. Art Therapy for Groups: A handbook of themes and exercises. Hove: New York: Bruner-Routledge, 2004.

Liebmann, Marian. Art Therapy for Groups: A handbook of themes and exercises. Hove: New York: Bruner-Routledge, 1986.

Lusebrink, Vija B. and Palo Alto, "Art Therapy and the Brain: An Attempt to Understand the Underlying Processes of Art Expression in Therapy.” 125-135.

Malchiodi, Cathy A. The Art Therapy Sourcebook $2^{\text {nd }}$ Edition. Hove: New York: Bruner-Routledge, 2007.

Malchiodi, Cathy A. The Handbook of Art Therapy. New York: The Guilford Press 2003.

Nakamura, Jeanne and Mihalyi Csikszentmihalyi, "The Concept of Flow." in Handbook of Positive Psychology, ed. Charles R. Snyder and Shane J. Lopez (Oxford: Oxford Univeristy Press, 2002), 89-105.

Robson, Colin. Real World Research: A Resource for Social Scientists and Practitioner - Researchers 3rd Edition. Oxford: Blackwell Publishers ltd, 2011.

Rubin, Judith. The Art of Art Therapy: What Every Art Therapist Needs to Know. Routledge: New York: East Sussex, 2011.

Sanders, Elizabeth and Pieter Jan Stappers, "Co-creation and the new landscapes of design.” CoDesign 4, March, (2008): 5-18.

Silverstone, Liesl. Art Therapy Exercises: Inspirational and Practical Ideas to Stimulate the Imagination. London: Jessica Kingsley Publishers, 2009.

Voytilla, Amy. "Flow states during art making." MA diss., The School of the Art Institute of Chicago, 2006.

Emily Corrigan-Doyle is a $\mathrm{PhD}$ researcher from Loughborough University. She is originally from Dublin, Ireland and her work explores at how design and art can be used to improve sustainability and happiness in the home. In particular, her research investigates ways that art therapy techniques within service design can facilitate happiness and sustainability in this context.

Emily began her higher education career at DIT School of Art, Design and Printing with a BA (Hons) Visual Communication degree, completing her thesis 
'Body Identification as an Entrance to the Idyllic Worlds Portrayed by Cosmetic Advertisements: A Study into Western Women's Menstrual Advertisements', graduating with distinction. She continued her career with an MA in Design: Critical Practice at Goldsmiths, University of London, also graduating with distinction, where she completed her Masters major project, a speculative design piece entitled 'Mind Entity Technology' which explored the complexities of human nature and its role in emotional well-being.

She started her PhD study at Loughborough Design School in October 2014, after winning a fully funded studentship at The Service Design Mini Centre for Doctoral Training. She has in this time presented a paper (ranked in top 30) at Sustainable Innovation 2015 conference and has presented posters at DesRes2015, Loughborough University and 'Better by Design', Lancaster University. Her current research interests include art therapy, sustainable design, creative methods in design research, happiness, well-being, positive psychology, service design, emotional design, social innovation, and environmental arts practice.

Dr Carolina Escobar-Tello is a forward thinking researcher, lecturer, and facilitator. Sustainability, creativity, systemic thinking, and a pro-active mindset shape her role as a designer and citizen of the world. She has worldwide professional design experience in the industrial and governmental arena. In addition she has extensive experience in design teaching and facilitating workshops ranging from the academia to the industry. Currently a Lecturer in the Design School at Loughborough University (UK), her work has been published in journals and international peer reviewed conference proceedings. Carolina's research looks at facilitating the transition towards increasing sustainable design practices by understanding better the design characteristics of products, services and systems that contribute to people's happiness and sustainable lifestyles. She is particularly interested in uncovering grass-root opportunities that help people to innovate and shape more sustainable societies.

She is an expert in Sustainable Design and active member of the Design Research Society Special Interest Group Sustainability, UK. In 2013 Carolina won a HE Social Entrepreneurship Award for her design framework and toolkit 'Design for Happiness'. This award gave way to establishing 'Riant by Design', a company whose overarching aim is to support communities, businesses and organisations in their transition towards more sustainable and happier lifestyles. This, in turn, seeks to generate a positive impact on social capital and innovation; and consequently economic prosperity.

Dr. Kathy Pui Ying Lo is the Academic Lead of The Service Design Mini Centre for Doctoral Training at Loughborough University, UK. She is also Lecturer in Visual Communication in School of the Arts. Kathy has extensive research experience in service design, experience design, emotional design, interaction 
design, and visual communication. Her recent research aims at facilitating positive transformations through service design and innovation. She is interested in achieving impact in quality of life, innovative ways of living, meaningful use of technology, and social innovation. Funding bodies of Kathy's research and activities include EPSRC, AHRC, and The Saudi Arabian Cultural Bureau.

Kathy holds a PhD in Design and an MA in Design (with distinction) from School of Design, The Hong Kong Polytechnic University. Her experiences and professional background cross boundaries between design, communication, social science, psychology, journalism, tourism and hospitality. She was the manager of an interactive design agency and worked on design projects for leading companies including Disney, Motorola, Peninsula Hotel, and Singapore Airlines.

Kathy was a conference track chair in service design. She also gives keynote speeches and guest lectures on her research areas. Kathy's recent research includes: Service design for social harmony between tourists and local communities, relational messages in design, hybrid touchpoints for service involving online and real-life interactions, emotional design for tourism and hospitality experiences, social enterprise for sharing home-grown fruits through digital mapping, and codesign of augmented reality. Kathy's research approach is inter-disciplinary, strategic and user-centered. She has made contributions by offering not only original concepts but also applicable strategies and real-world cases. Kathy's most recent publications can be found in International Journal of Design, Design and Culture Journal, and conference proceedings such as Design and Emotion Conferences, NordDesign Conference, and IASDR Conference etc. 